San Jose State University

SJSU ScholarWorks

Master's Theses

Master's Theses and Graduate Research

1990

\title{
The relative effects of diet and irradiance on the growth and survival of post-larval red abalone, haliotis rufescens
}

Susan C. McBride

San Jose State University

Follow this and additional works at: https://scholarworks.sjsu.edu/etd_theses

\section{Recommended Citation}

McBride, Susan C., "The relative effects of diet and irradiance on the growth and survival of post-larval red abalone, haliotis rufescens" (1990). Master's Theses. 3277.

DOI: https://doi.org/10.31979/etd.tjt2-939a

https://scholarworks.sjsu.edu/etd_theses/3277

This Thesis is brought to you for free and open access by the Master's Theses and Graduate Research at SJSU ScholarWorks. It has been accepted for inclusion in Master's Theses by an authorized administrator of SJSU ScholarWorks. For more information, please contact scholarworks@sjsu.edu. 


\section{INFORMATION TO USERS}

The most advanced technology has been used to photograph and reproduce this manuscript from the microfilm master. UMI films the text directly from the original or copy submitted. Thus, some thesis and dissertation copies are in typewriter face, while others may be from any type of computer printer.

The quality of this reproduction is dependent upon the quality of the copy submitted. Broken or indistinct print, colored or poor quality illustrations and photographs, print bleedthrough, substandard margins, and improper alignment can adversely affect reproduction.

In the unlikely event that the author did not send UMI a complete manuscript and there are missing pages, these will be noted. Also, if unauthorized copyright material had to be removed, a note will indicate the deletion.

Oversize materials (e.g., maps, drawings, charts) are reproduced by sectioning the original, beginning at the upper left-hand corner and continuing from left to right in equal sections with small overlaps. Each original is also photographed in one exposure and is included in reduced form at the back of the book.

Photographs included in the original manuscript have been reproduced xerographically in this copy. Higher quality 6" x 9" black and white photographic prints are available for any photographs or illustrations appearing in this copy for an additional charge. Contact UMI directly to order.
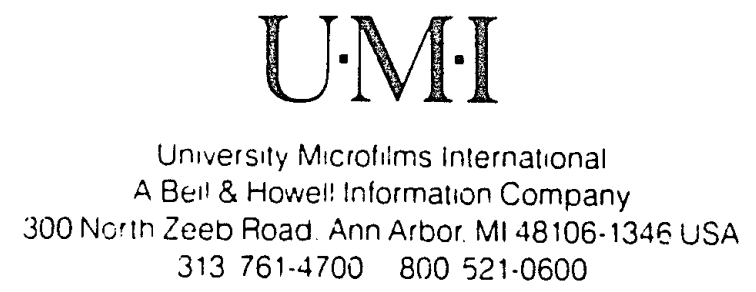

Order Number 1940590

The relative effects of diet and irradiance on the growth and survival of post-larval red abalone, Haliotis rufescens

McBride, Susan Christine, M.S.

San Jose State University, 1990

Copyright (C1990 by McBride, Susan Christine. All rights reserved.

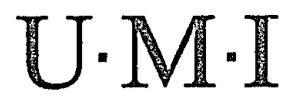

300 N. Zeeb Rd.

Ann Arbor, MI 48106 



\title{
THE RELATIVE EFFECTS OF DIET AND IRRADIANCE ON THE GROWTH AND SURVIVAL OF POST-LARVAL RED ABALONE, HALIOTIS RUFESCENS
}

\author{
a Thesis \\ presented to \\ The Faculty of the Department of Biology \\ San Jose State University \\ In Partial Fulfillment \\ of the Requirements for the Degree \\ Master of Science
}

By

Susan C. McBride

June, 1990 

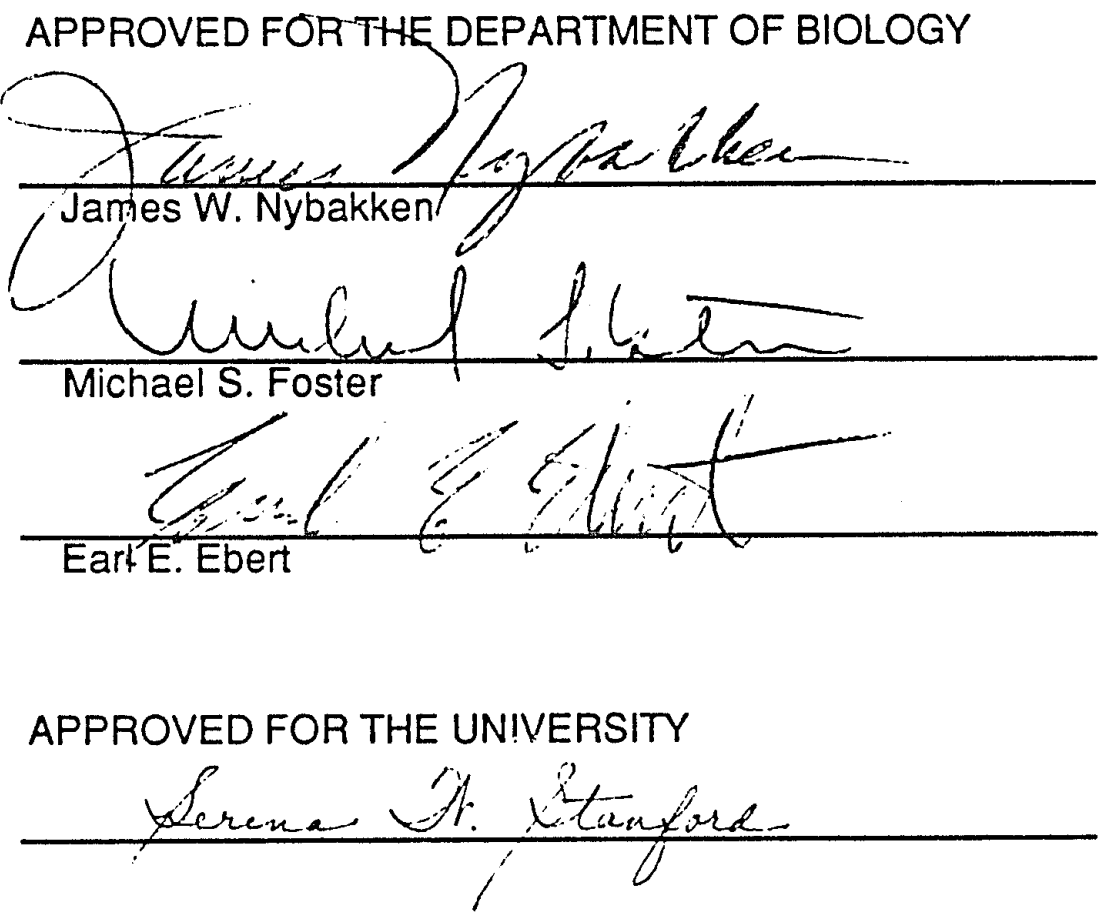


\title{
ABSTRACT \\ THE RELATIVE EFFECTS OF DIET AND IRRADIANCE ON THE GROWTH AND SURVIVAL OF POST-LARVAL RED ABALONE, HALIOTIS RUFESCENS
}

\author{
by Susan C. McBride
}

\begin{abstract}
A factorial experiment was conducted to determine the effect of unialgal diatom diets and irradiance levels on the growth and survival of post-larval red abalone, Haliotis rufescens. Competent larvae were introduced to test containers previously inoculated with unialgal diatom cultures. Three diatoms of similiar size were used, Navicula zostereti, Nitzschia bilobata, and Nitzschia closterium. Diatoms were supplied to the post-larvae in excess. The irradiance levels were 15 to $25 \mu \mathrm{E}$ and 50 to $60 \mu \mathrm{E}$. The photoperiod was set to simulate natural daylength.

All orthogonal factors and interactions tested resulted in significant differences between treatments. Shell length (growth) and proportional survival were greater in the high irradiance treatment. The rank order of diatoms showing the greatest to the least growth are N. bilobata, N. zostereti, and $N$. closterium. Significant interactive effects between main factors warned of inconsistent relationships between these factors.
\end{abstract}




\section{Acknowledgements}

I would like to thank Drs. James W. Nybakken and Michael S. Foster for their assistance in designing the experiment and editing the manuscript. Many special thanks to Earl E. Ebert for encouraging my research interests. Thanks also to Sheila Baldridge and Sandy O'Neil for continually finding appropriate literature. I am grateful to the Department of Fish and Game Marine Resources Laboratory for providing the facility and space to complete this work. Thanks to the staff of the Marine Pollution Studies Laboratory for many helpful suggestions with this project. Thanks also to Dr. R. Holmes for help with diatom taxonomy and Dr. A. U. I'ncierwood for getting me started on linear models for analysis of variance. I am extremely grateful for the constant encouragement of my family and friends throughout the course of this experiment.

This work was funded by the Dr. Earl H. and Ethel M. Myers Oceanographic and Marine Biology Trust, the Western Society of Malacologists, the Conchologists of America, and the International Women's Fishing Association. Their support is gratefully acknowledged. 


\section{Table of Contents}

$\begin{array}{ll} & \text { Page } \\ \text { Abstract } & \text { iii } \\ \text { Acknowledgements } & \text { iv } \\ \text { Table of Contents } & \mathrm{v} \\ \text { List of Tables } & \mathrm{vi} \\ \text { List of Figures } & \mathrm{vii} \\ \text { Introduction } & 1 \\ \text { Material and Methods } & 4 \\ \text { Results } & 9 \\ \text { Discussion } & 15 \\ \text { Literature Cited } & 22 \\ \text { Tables } & 27 \\ \text { Figures } & 35 \\ \text { Appendix } & 45\end{array}$




\section{List of Tables}

Table

Page

1. Diatom inocula 27

2. Mean shell length of abalone larvae 28

3. Analysis of variance: abalone shell length 29

4. Abalone growth rates 30

5. Arralysis of variance: abalone survival 31

6. Diatom cell density 32

7. Diatom chl a content 33

8. Diatom $\mathrm{CHN}$ analysis 34 


\section{List of Figures}

Figure

Page

1. Experimental design 35

2. Effect of light and time on abalone shell length 36

3. Effect of diet and time on abalone shell length 37

4. Effect of diet and light on abalone shell length 38

5. Abalone growth rates from all treatments 39

6. Growth rate comparisons 40

7. Mean shell length comparisons 41

8. Effect of light and time on abalone survival 42

9. Effect of diet and light on abalone survival 43

10. Effect of diet and time on abalone survival 44 
Introduction

Growth and survival of post-larval Haliotis rufescens are potentially influenced by behavior, development, and diet. Entry into the post-larval life stage is complicated by a rapid and dramatic behavioral metamorphosis from a swimming larva to a benthic, creeping post-larva. Complex interactions of the physical and chemical characteristics of the substrate regulate this behavioral metamorphosis (Morse, 1984; Hadfield, 1984). The post-larval period begins at metamorphosis with the secretion of the adult shell form. It is well established that many marine invertebrate larvae complete metamorphosis without feeding (Crisp, 1974). However, recent research has shown that lecithotrophic "nonfeeding" larvae of Haliotis rufescens uptake amino acids in seawater (Jaeckle and Manahan, 1989a). These "non-feeding" larvae cannot feed on particulate matter but may acquire energy from dissolved organic material in seawater (Jaeckle and Manahan, 1989b). Larval rearing of Haliotis spp. is usually conducted in one micron, ultra-violet irradiated seawater. This highly treated seawater is known to contain significantly less dissolved organic material than unfiltered seawater (Manahan and Stephens, 1983). Thus at the time of settlement the amount of yolk material required for early post-larval clevelopment may be depleted due to the larval rearing conditions. This lower energy store may increase the importance of the first particulate diet available to the post-larval abalone. When the larvae have settled and metamorphosed into benthic, crawling post-larvae, $H$. rufescens larvae begin feeding (Hooker and Morse, 1985). Concurrent with the first, benthic, particulate feeding, the complete physical development of the internal anatomy continues until the formation of the first respiratory pore approximately two months later. Completion of this pore indicates the end of the post-larval life stage (Crofts, 
1937; Leighton, 1972). Exact nutritional requirements during the post-larval period are generally unknown.

When the digestive tract of $H$. rufescens, two to six days postmetamorphosis, were examined, diatoms of the Order Pennales were found (Norman-Boudreau et al, 1986). All diatoms were less than $10 \mu \mathrm{m}$ in width. The largest, Synedra sp., was $30 \mu \mathrm{m}$ in length and $5 \mu \mathrm{m}$ in width. Post-larval abalone in most studies are commonly fed benthic diatoms that adventitiously settle on surfaces of rearing containers. These mixed populations of benthic diatoms have been successfully used to settle and rear post-larval Haliotis spp. in California, South Africa and Japan (Ebert and Houk, 1984; Genade et al, 1986; Oba, 1964; Seki, 1980). In France and Mexico a green alga, Tetraselmis suecia, was used in addition to benthic diatoms for post-larval forage (Flassch and Woitellier, 1977; Searcy-Bernal et al, 1989).

Typical diatom genera used in these studies are Amphora, Cocconeis, Grammotophora, Navicula, Nitzschia and Synedra. Typical survival of postlarval abalone until two months ranges from one to twelve percent (Ebert and Houk, 1984). Their growth is slow but more or less continuous (Leighton, 1974). Some of these differences may be attributed to the specific diatoms available to the young abalone. In this study, three benthic, pennate diatom cultures were developed to examine their effects on post-larval $H$. rufescens growth and survival.

Most researchers agree the initial diet is important iri determining survival and growth in post-larval Haliotids (Ebert and Houk, 1984; Leighton, 1977; Kan-ho,1975). Paradoxically, the light required to culture sufficient diatoms in post-larval abalone rearing tanks may inhibit their growth. Feeding behavior in juvenile abalone is suppressed by high irradiances. Because of this, growth 
rates are enhanced by subdued light or total darkness (Shibui, 1971; Uki, 1981). The effect of light irradiance on post-larval abalone growth and survival has not been directly addressed. The influence of light irradiance in the range of 60 to $80 \mu \mathrm{E}$ was noticed to coincide with the highest growth and survival rates of $H$. tuberculata during the first fifteen days of the post-larval period (Flassch and Woitellier, 1977). To determine the influence of diatom species and irradiance on post-larval $H$. rufescens, the effects of three diatom diets and two irradiance levels on their growth and survival were examined. 


\section{Materials and Methods}

This work was done at the California Department of Fish and Game Marine Resources Laboratory located 20 kilometers south of the Monterey Peninsula (N. lat. $36^{\circ} 26^{\prime}$, W. long. $121^{\circ} 55^{\prime}$ ). The laboratory is continuously supplied with seawater pumped directly from the ocean (Ebert et al, 1974). This work was done over a ten week period from June to August 1989. Seawater temperature was maintained at 12 to $15^{\circ} \mathrm{C}$ and the salinity ranged from 33 to 34 ppt.

Changes in growth (shell length) were determined relative to three orthogonal factors, diet $\left(\mathrm{D}_{i}\right)$, light $\left(\mathrm{L}_{j}\right)$, and time $\left(\mathrm{T}_{k}\right)$ and one nested factor, containers, $[C(D L T) \mid(i j k)]$. Groups of post-larvae were kept at each of the six combinations of diet and light. Three replicate containers of each treatment were destructivley sampled and preserved every two weeks.

The linear ANOVA model for this design is: $x_{i j k l m}=\mu+D_{i}+L_{j}+D_{i j}+T_{k}$ $+D T_{i k}+L T_{j k}+D L T_{i j k}+C(D L T)_{\mid(i j k)}+e_{m(i j k l)}$ where $\mu$ is the grand mean and $e$ is the error term. The estimation of mean square values for each source of variation (Underwood, 1981) is shown in Appendix 1.

The proportional abalone survival data were analyzed by a Three Way Model 1 ANOVA (Sokal and Rohlf, 1981). For both the abalone shell length data and the proportional abalone survival data, Newman-Kuels test (Winer, 1971) was used to find significant differences between sample means. The test for importance (Weldon and Slauson, 1986; Sokal and Rohlf,1981) was used to determine the relative contribution of each factor or interaction to the total variation. The test for importance relies on the fact that the explained sums of squares must be smaller than the total sums of squares. A measure of 
importance is the ratio of the factor sums of squares over the total sums of squares. The importance of uncontrolled factors is represented by the error sums of squares over the total sum of squares.

A total of 162 test containers were randomly interspersed on the experimental water table, 24 for each of the six diet-light combinations and 18 as diatom controls (Figure 1). At two week intervals, post-larvae from three replicates of each treatment were collected on a $90 \mu \mathrm{m}$ sieve. For an estimation of growth, the first five, live abalone with undamaged shell edges were measured to the nearest $0.005 \mathrm{~mm}$ with an ocular micrometer at $40 \mathrm{X}$. All live and dead animals were counted and the sample preserved.

The shell lengths of the post-larval red abalone from two miscellaneous spawnings conducted at the Marine Resources Laboratory during 1988 were used in qualitative comparison to the data collected during this experiment. Growth rates were calculated from both sets of data.

Three aliquots of a diatom sample from each test container were counted on a Brite Line Improved Neubauer hemacytometer (Stein, 1973). A diatom sample of known volume was also collected on Millapore AA, $0.40 \mu \mathrm{m}$ pore filter and analyzed for chlorophyll a content (Parsons et al, 1984). Chlorophyll a (chl a) content was calculated according to the equations of Humphrey (1979). After sampling, the test containers were replaced to their original position to maintain uniform conditions for the duration of the experiment.

Diatom control containers contained no abalone. They were inoculated with the same diatom cell density as the abalone treatment containers, but at each two week interval all diatoms were removed from the control containers and sampled as described above for cell density and chl a content. These data 
were used qualitatively to assess the amount of each diatom diet available to the post-larvae in the test containers. In the abalone test containers, new diatom inocula were added every two weeks.

The diets supplied to the post-larval abalone were unialgal but not axenic cultures of Nitzschia bilobata (N. bilobata), Nitzschia closterium ( $N$. closterium), and Navicula zostereti (N. zostereti). These three common species of sessile, benthic diatoms were isolated by capillary pipette (Stein, 1973) and grown in sterilized seawater (Keller et al, 1988). The established cultures were transferred to 11 liter polyethylene buckets with flowing seawater as media. The diatoms readily attached and grew on the sides of the buckets and test containers. The incoming seawater to both the test containers and the diatom cultures was treated by $1 \mu \mathrm{m}$ cartridge filtration and UV irradiation.

The lighting system was two General Electric Chroma $50 \odot$ flourescent bulbs placed $20 \mathrm{~cm}$ above the experimental water table. The spectra of light emitted from the Chroma 50 bulbs simulated natural light conditions penetrating coastal waters at $0-10 \mathrm{~m}$ depth (Jerlov, 1976). Light measurements were made at the water surface of the test containers every two weeks with a Licor LI185 integrating quantum / radiometer / photometer. (Irradiance in the photosynthetically active region, 400 to $700 \mathrm{~nm}$, was measured in microeinsteins, photons $m^{-2} s^{-1}$ ).

The light treatment was segregated. A piece of plastic window screen suspended from the wooden frame supports at either end of the bulbs shaded the two far ends of the water table. This structure provided two light treatments, a central high irradiance of 50-60 $\mu \mathrm{E}$ and two low irradiance areas of $15-25 \mu \mathrm{E}$. The irradiance available to ten species of benthic, estuarine diatoms, including 
Nitzschia spp. and Navicula spp., was in the range of 20 to $85 \mu \mathrm{E}$ (Admiraal, 1977). These levels of irradiance produced light saturated growth in all ten species. The lights were controlled with an electric timer to simulate natural day length.

A manifold with an individual line and control valve for each test container supplied each test container with $33-37 \mathrm{ml} / \mathrm{min}$ of running seawater (Figure 1). The turnover time per container of 35 to 45 minutes was determined by dye tests.

The test containers were one liter polyethylene freezer storage boxes, $10.5 \times 10.5 \times 13.0 \mathrm{~cm}$. The total surface area available to the abalone and diatoms was $580 \mathrm{~cm}^{2}$. A $0.5 \times 1.5 \mathrm{~cm}$ hole for drainage was made $0.5 \mathrm{~cm}$ below the rim and covered with $180 \mu \mathrm{m}$ Nitex mesh. The volume of seawater in each test container was $920 \mathrm{ml}$. The containers were uncovered for the duration of the experiment.

The manifold tubing and valves were also made of polyethylene. All test containers and manifold supplies were washed in Alconox(C), rinsed in freshwater, left submerged in running filtered seawater for one month and then washed again before use in the experiment.

Abalone larvae were obtained in May 1989 from an induced, synchronous, mass spawning of eight adult $H$. rufescens. The adult abalone were artificially conditioned first and second generation laboratory reared broodstock. Larvae were reared according to Ebert and Houk (1984). Competent, $0.262 \mathrm{~mm}$, larvae were collected on sieves, counted, measured and distributed at 200-300 per test container. In several studies, this larval settling density had the greatest survival for the post-larval period (Leighton, 1985; 
Ebert and Houk, 1984; Inoue, 1976; Shibui, 1972). Each test container and diatom control container were inoculated with one of the unialgal cultures 24 hours prior to introduction of abalone and every two weeks during the experiment (Table 1).

After completion of the experiment, one sample of each diatom species was tested for carbon, hydrogen and nitrogen ( $\mathrm{CHN}$ analysis) using a Controlled Equipment 240XA elemental analyzer. 


\section{Results}

For the remainder of this paper, time $1,2,3,4$, and 5 are synonomous with ages $3,5,7,9$, and 11 weeks respectively.

\section{Abalone Shell Length}

Results of Chi Square Goodness of Fit Test for Normality (Zar, 1984) of all shell length data showed that the size frequency distributions of the observed abalone shell lengths did not differ significantly from the expected frequencies $\left(X^{2}=17.131, d f=9, p=0.0467\right)$. Cochran's Test for Homogeneity of Variance (Winer, 1971) showed no significant differences between sample variances $(C=0.7457, k=3, d f=4, p=0.05)$. The results of these tests indicated that the use of parametric statistics on the growth data were appropriate.

A qualitative comparison of three samples from the total larval population used at the start of the experiment indicated there were no significant differences between the initial shell lengths (Table 2).

Manipulation of diet and light treatments over the 10 week period resulted in significant differences in abalone shell length for all factors and interactions tested (Table 3). The significance of the main effects and the interaction terms allows the analysis in the presence of the significarit container effect (Underwood, 1981). However, the significant second order interaction warns that effects of one facior are not constant over levels of other factors (Scheffe, 1959; Underwood, 1981). For this reason each factor was tested for significant differences over each level of the other two factors.

There were no significant interactions between light and time at times 1 , 2 , and 3 (Figure $2 a$ and $b$ ). The light and time interaction showed significant differences between means at times 4 and 5 for high irradiance. Abalone on 
the $N$. bilobata diet had significantly greater shell length than those fed $N$. zostereti and $N$. closterium. In the low light treatment, $N$. bilobata exhibited greater growth than $N$. zostereti and N. closterium at times 3 and 4 . At time $5, N$. bilobata and $N$. zostereti had greater growth than $N$. closterium (Figure 2c, $d$ and $e$ ). The significant differences are represented by the distance between vertically arranged points on all graphs. The interactions are represented by non-parallel lines (Winer, 1971). This interaction contributed 0.05 to the total explainable variation.

Diet and time interacted significantly at time 5. The abalone on the $\mathrm{N}$. bilobata diet, high irradiance environment had significantly greater growth over all other treatments except $N$. zostereti high irradiance treatment. This interaction contributed 0.02 of the total variation (Figure 3a and b).

Neuman-Kuels test for differences between treatment means indicated significant differences between the diet and light interaction for times 3, 4 and 5 for N. zostereti and N. bilobata and for time 3 and 4 for N. closterium. This interaction is shown geometrically in the non-parallel lines of each diet at each irradiance. In all cases, growth was greater in the high irradiance treatment (Figure $4 a, b$ and $c$ ). The proportion of total variance explained by the diet and light interaction is 0.01 .

The main factors of diet, light, and time contributed $0.03,0.06$ and 0.65 , respectively, of the total explainable variation in this analysis. When the main effects are averaged over the levels of the other two factors to test for effects of the third factor, the conclusion is a significant difference but no constant relationship can be inferred due to the significance of the first and second order interactions (Scheffe, 1959; Underwood, 1981). 


\section{Abalone Growth Rate}

Sample means were used to calculate growth rates ( $\mu \mathrm{m} / \mathrm{day}$ ) of the experimental post-larvae from all diet and irradiance treatments (Figure 5, Table 4). Abalone in all treatments decreased in growth rate between 3 and 5 weeks of age and increased in growth rate until 7 weeks of age. The decrease in growth rate for all treatments between 3 and 5 weeks may reflect developmental changes such as the protrusion of epipodial tentacles on both sides of the foot, enlargement of the digestive gland, and elongation of the intestine (Crofts, 1937; Oba, 1964; Koike, 1978). From 7 weeks until 11 weeks of age, the growth rate was variable between treatments. The post-larvae in the $N$. bilobata, high irradiance treatment had the greatest growth rate throughout the experiment.

The growth rate of the post-larvae from the N. bilobata, high irradiance treatment were similiar to those of the abalone from the two miscellaneous spawnings of 1988. It is interesting to note that abalone fed a unialgal diet in the test containers grew at a rate equivalent to abalone reared in a 260 liter tank with a rnixed diatom diet (Figure 6). The shell lengths of these three groups of abalone were also similar (Figure 7).

\section{Proportional Survival}

Proportional survival data were collected for eight weeks as the number of live abalone divided by the total number of live and dead abalone per test container. The proportional survival data were transformed to degrees by $\arcsin \sqrt{ } x$ to remove heterogeneity of variance (Underwood, 1981). All following statistical analyses were performed on the transformed data. Chi Square Goodness of Fit for all observed survival data showed no significant differences 
$\left(X^{2}=13.088, d f=7, p=0.07\right)$. There were no significant differences between sample variances at $C=0.8643, d f=2, k=4, p=0.05$ (Cochran's Test, Winer, 1971).

Results of the 3 Way ANUVA showed significant second order interactions, requiring a separate analysis of each contributing first order interaction (Table 5). The light and time interaction showed significant differences between means at time 1 for $N$. bilobata and $N$. closterium in the high irradiance. At time 2, survival was greatest on N. bilobata for both high and low irradiance. There were no significant differences between sample means at time 3. Abalone survival was greater on N. bilobata than $N$. closterium and N. zostereti at the low irradiance for time 4. Survival of abalone fed $N$. bilobata was greater than survival on N. closterium in the high irradiance at time 4 (Figure $8 a, b, c$ and d). The proportion of the variance explained by this interaction is 0.08 .

The diet and light interaction for $N$. zostereti showed greater abalone survival in high irradiance at times 2 and 4 . Abalone survival was greater on $N$. bilobata at time 2 and showed no significant differences at all other times (Figure 9a). Abalone fed N. closterium had greater sursival at low irradiance, time 1 and no significant differences at all other times (Figure 9b). At time 3 , there was a greater proportional survival of post-larval $H$. rufescens at the low irradiance (Figure 9c). This interaction contributed 0.02 to the total explainable variance and was not significant in the 3 Way ANOVA.

The diet and time interaction resulted in significant differences in mean proportional survival between $N$. bilobata and $N$. closterium at both high and low irradiances for times 1, 2, and 4. At times 2 and $4, N$. zostereti and $N$. 
closterium also had signiticant differences between their sample means at both high and low irradiances. At time 3, there were no significant differences between any sample means (Figure 10a and $b$ ). This interaction contributed 0.14 of the total variation and was not significant in the 3 Way Anova.

The main factors of diet, light, and time contributed $0.33,0.02$, and 0.08 , respectively, to the total variation. Diet and time were both significant at the level tested. Light was not found significant in this analysis. Conclusions about light interactions are significant because the diet and time main effects are non-zero. Their contributions are sufficient in the interactions Sums of Squares containing light as a factor to show significant effects (Scheffe, 1959; Winer, 1971). The contributions to the total variance by the non-significant factors and interactions of the ANOVA are the lowest values of all sources.

\section{Diatoms}

Qualitative examination of cell densities in the control and abalone grazed containers (Table 6 ) relative to the inoculum (Table 1 ) indicates diatoms maintained their populations or reproduced in all but two cases. N. closterium decreased in cell density in the control, low irradiance treatment at time 2. $N$. bilobata decreased in cell density with abalone at low light, time 1. Neither of these exceptions corresponded with a significant multiple comparison in the abalone shell length or proportional survival analyses.

Chl a data were coilected at times 1,4, and 5. Chl a content increased with cell density over time (Table 7 ). The $N$. closterium sample at time 5 , low irradiance with abalone may be a measurement error. 
somewhat higher than for the other two species, but nitrogen values are similar. The $\mathrm{C} / \mathrm{N}$ ratios of 5 to 6 indicate the diatoms were nutrient saturated (Jahnke, 1989; Table 8). 


\section{Discussion}

The main objective of this study was to determine the effects of diet and irradiance on post-larval $H$. rufescens growth and survival. The results indicate $H$. rufescens growth and survival are higher on N. bilobata than $N$. zostereti or N. closterium. Even though growth was not significantly different until time 3 , (age 5 weeks), qualitatively, growth was greater on N. bilobata regardless of age. Survival was always greater on $N$. bilobata at high irradiance.

Slow growing abalone have been shown to remain so compared to their siblings (Leighton, 1974). This is usually attributed to genetics but in this case it may be partially from the nutritional history of the abalone. If the postlarvae did not receive sufficient energy from the diet offered, the developmental process would slow or halt and the abalone die or become stunted. From the data, it appears that stunting and a higher mortality occurred on the $N$. closterium diet.

Time was the most pronounced factor affecting post-larval abalone growth in this study. Differential growth on the three diets and the increase in growth rate of the abalone fed $N$. bilobata in the last two weeks of the study were responsible for the significance of the time factor. N. closterium ted abalone remained slow growing. The abalone fed $N$. zostereti were intermediate and somewhat more erratic in their growth, appearing to approach growth rates of the abalone fed $N$. bilobata at the end of the experiment. The abalone fed $N$. bilojata were consistently faster growing. Due to the faster growth rate, the abalone fed $N$. bilobata reached the end of the post-larval life stage and began the accelerated growth of juvenile abalone during the last two 
weeks of the experiment (Clavier and Richard, 1986; Koike, 1978; Hayashi, 1982). This increased growth rate added to the significance of time as a factor affecting growth of the abalone in this study.

Post-larval $H$. rufescens are often observed feeding within 20 hours of settlement (E. Ebert, pers. comm.). In two other studies, feeding began from 2 to 6 days post-settlement (Morse, 1981; Norman-Boudreau et al, 1986). At settlement, the mouth diameter is $10 \mu \mathrm{m}$ and by 48 hours it is $30 \mu \mathrm{m}$ (Hahn, 1989). The diatoms offered in this study were 5 to $8 \mu \mathrm{m}$ in width and 20 to 35 $\mu \mathrm{m}$ in length. This is within the size range of diatoms found in the digestive tract of $H$. rufescens two days post-settlement (Norman-Boudreau et al, 1986). When the abalone feed during the first two days post-settlement, their nutritional needs may be met by bacteria associated with the diatoms. Post-larval $H$. ruber are known to feed on the bacteria associated with coralline algal crusts. The importance of the bacteria to the post-lanvae is unknown (Garland et al, 1985).

The first 2 to 4 days post-settlement may also be influenced by parental yolk allotment (Leighton, 1972). The high fecundity of these animals lends some support to this idea. At the time of first reproductive maturity, female $H$. rufescens are $40 \mathrm{~mm}$ in length and release approximately one million eggs (Ebert and Houk, 1984). A twelve to thirteen $\mathrm{cm}$ female $H$. rufescens may release up to 11 million eggs (Hahn, 1989). The amount of yolk material in each egg may not be equal. Post-larvae with energy reserves remaining from the yolk may have increased survival and/or growth potential for the first days following settlement.

The first 100 hours of post-larval growth was enhanced by providing specific physiological requirements (Morse,1981). Efficient induction of 
settlement and metamorphosis and the synchronous start of post-larval growth was achieved by providing competent $H$. rufescens larvae with a specific amino acid, g-aminobutyric acid. The subsequent growth was accelerated during this 4 day experiment with the addition of mammalian growth hormones and insulin resulting in an average growth rate of $65 \mu \mathrm{m} /$ day. In the present study, diatom diet had a significant effect on growth and survival of post-larval $H$. rufescens without the addition of exogenous compounds although such high growth rates were not achieved (Table 4).

The feeding organ of the post-larvae, the radula, consists of 8 to 10 rows of broom like marginal teeth which sweep the substrate to rernove food items (Dinamani and McCrae, 1986). Cell size, morphology and cell wall thickness may mechanically affect the ability of the radula to remove particles from the substrate. The apical extremities of $N$. closterium may also have presented a mechanical problem and affected their overall digestibility. Relative cell wall thickness of the three diatom species used in this study are unknown. Thicker cell walls may reduce the digest:bility of cell contents by digestive enzymes present in the post-larval stomach (Crofts, 1937).

If the abalone were feeding at equal rates on all diets, the differential growth and survival may have reflected a lag time in development of digestive enzymes from nutritional deficiencies of $N$. closterium and $N$. zostereti. Specific unialgal diets of diatoms and green algae have been used to increase production of mass cultured larval oysters, clams, and mussels (Manzi et al,1985, Bayne et al, 1987, ). These planktonic larve feed after depleting yolk reserves. During this period, the quality of the food, determined by growth of the larval bivalves and the survival of the resulting spat, is greatiy influenced by 
storage of energy reserves from the food consumed (Helm et al, 1973). There is however a lag phase when yolk material is depleted concurrent with increased morphogenic activity and a lowered growth rate (Whyte et al, 1987; Holland and Spencer, 1971). This response is similiar to the post-larval $H$. rufescens settlement and early growth. When the parental yolk reserves are used during settlement and metamorphosis the following growth is slow probably due to similar delay in metabolic activity and development of digestive processes. This could partially explain the significant differences occurring in shell length at 5 weeks of age for post-larval abalone.

Overall the abalone in this study grew more rapidly in the high irradiance treatment. Diatom cell biochemistry may have contributed to this accelerated abalone growth. In general, when diatoms are placed in a different irradiance environment, the cells respond by increasing the amount of chl a per cell or increase the rate of photosynthesis (Beardall and Morris, 1976). Chl a analysis suggests the amount of chl a per cell did not increase in the low irradiance treatment. However, the photosynthesis rate may have increased in the high irradiance treatment. The abalone in the high irradiance treatment would then benefit from increased oxygen concentration. Inefficient respiration is one factor that may limit post-larval abalone growth (Crofts, 1937).

In the invertebrate phyla, irradiance effects have been most intensively studied in insects. Insect response to light ceases at the lower limit of bud initiation in plants, $1 \mu \mathrm{E}$ (Lees, 1968). For example the Oriental fruit moth, Grapholitha molesta, feeding activity inside apple fruit continues at $3 \mu \mathrm{E}$ but not at $1 \mu \mathrm{E}$. Also as irradiance is progressively reduced, the growth response of larval rice stem borers, Chilo suppressalis, ceases to occur. A parallel situation 
may have occurred with the abalone in the low irradiance treatment fed $N$. closterium. The growth rate found on the $N$. closterium diet was nearly constant for the duration of the experiment suggesting a stunted growth, possibly in response to low irradiance.

It is generally accepted that the nutritional value of different algal diets is not the same. However, studies on marine phytoplankton cultured in the same experimental conditons have very similar organic chemical composition (Parsons et al, 1961; Chu et al, 1982). Nevertheless, two of the four diatoms studied by Parsons et al (1961) did contain 10\% more crude carbohydrate than the other 9 species representing four families. In marine, pennate diatoms this material may be present on the outside of diatom cells as they move over the substrate. Diatoms are known to contain carbohydrate associated with the silica of frustules (Fogg, 1965). This material would be more accessible to the abalone than carbohydrate inside the frustule. It seems reasonable to suggest N. bilobata cells produced more of this 'crude' carbohydrate than the other two species. The food value of phytoplankton for the scallop, Patinopectin yessoensis, showed a high correlation between carbohydrate content of the cells and larval growth (Whyte et al, 1989).

Two other studies have shown little correlation between the carbohydrate, lipid, and protein content of algae used as food items to cultured bivalves and their nutritional value. Epifanio (1979) reported growth of hard and soft tissue on juvenile American oysters, Crassostrea virginica, and hard clams, Mercenaria mercenaria, was not correlated with the amount of carbohydrate, lipid, protein or amino acid in the diets. Instead it was related to the presence or absence of a particular algal species in the diet. It is possible 
once the biochemical balance of protein, lipid, and carbohydrate has been achieved by the combination of several species of algae, other biochemical components such as trace metals and vitamins are present in adequate amounts to promote growth (Chu et al, 1982). If this is the case, $N$. bilobata most closely matched the virtually unknown nutritional requirements of postlarval abalone and use of this diatom species in conjunction with other diatoms may enhance post-larval abalone growth.

Comparison of mean, post-larval, abalone shell lengths between this study and miscellaneous spawnings at the Marine Resources Laboratory indicate that use of unialgal cultures did not increase growth. For example, mean size of 11 week post-larvae spawned in February and June 1988 were, 1.86 and 1.74 compared to 1.78 for the abalone in the N. bilobata, high irradiance environment. However, the use of unialgal cultures at this critical life stage shows a pronounced benefit towards their survival, indicating post-larval abalone need the diatoms to continue their existence. Proportional survival of abalone fed $N$. bilobata was $55-70 \%$ while the two spawnings mentioned above had $6 \%$ and $10 \%$ survival, respectively. In a commercial operation, consistent yield of post-larvae would allow adjustment of the hatchery system to known levels of production and greater efficiency.

When energy is sufficiently converted to allow for growth, time was the most pronounced factor influencing growth of post-larval abalone. The three diets supplied to the post-larvae allowed their continued growth but at different rates. At the completion of the experiment, the abalone fed $N$. bilobata were $20 \%$ greater in shell length than abalone fed $N$. zostereti and $25 \%$ greater than those fed N. closterium. Survival on N. bilobata was $52 \%$ greater than $N$. 
closterium and $47 \%$ greater than N. zostereti. Growth and survival were overall greater in the high irradiance environment and diet also had a significant effect on these two parameters.

In the biological world, we usually have no knowledge that any one factor will exert its influence independently of all others that could be manipulated. In this experiment two factors which could be controlled (diet and light) and one which could be measured (time) were chosen for comparison of their effect on post-larval red abalone growth and survival. More knowledge of the effect of these factors was gained using the multifactorial design because every trial supplied information on the main factors as well as an estimation of the interactions between them. In a traditional one factor design or if a series of factors are tested singly, no interactive effects can be estimated. A factorial experiment is more informative and possibly more powerful and economical than smaller experiments. 


\section{Literature Cited}

Admiraal, W. 1977. Influence of Light and Temperature on the Growth Rate of Estuarine Benthic Diatoms in Culture. Mar. Biol., 39: 1-9.

Bayne, B.L., Hawkins, A.J.S., Navarro, E. 1987. Feeding and Digestion by the Mussel Mytilus edulis L. (Bivalvia:Mollusca) in mixtures of silt and algal cells at low concentrations. J. Exp. Mar. Biol. Ecol., 111: 1-22.

Beardall, J., Morris, I. 1976. The Concept of Light Intensity Adaptation in Marine Phytoplankton: Some Experiments with Phaeodactylum tricornutum. Mar. Biol., 38: 377-386.

Chu, Fu-Lin E., Dupuy J.L., Webb, K.L. 1982. Polysaccharide Composition of Five Algal Species Used as Food for Larvae of the American Oyster, Crassostrea virginica. Aquaculture, 29: 241-252.

Clavier, J., Richard, O. 1986. Growth of Juvenile Haliotis tuberculata (Mollusca: Gastropoda) in their Natural Environment. J. Mar. Biol. Assn. U.K., 66: 497-503.

Crisp, D.J. 1974. Factors influencing settlement of marine invertebrate larvae. in Chemoreception in Marine Qraanisms (edited by Grant, P.T. and Mackie, A.M.), 177-265. Academic Press, New York.

Crofts, D. 1937. The Development of Haliotis tuberculata, with Special Reference to Organogenesis During Torsion. Royal Society of London Phil. Trans. Series B, 229: 219-268.

Dinamani, M., McCrae, C. 1986. Paua Settlement. New Zealand Shellfisheries Newsletter, 30: 9.

Ebert, E.E., Haseltine, A.W., Kelly, R.O. 1974. Seawater system design and operations of the Marine Culture Laboratory, Granite Canyon. Calif. Fish and Game, 60(1): 4-14.

Ebert, E.E., Houk, J.L. 1984 Element and Innovations in the Cultivation of red abalone, Haliotis rufescens. Aquaculture, 30: 375-392.

Epifanio, C.E. 1979. Growth in bivalve molluscs: Nutritional effects of two or more species of algae in diets fed to the American Oyster, Crassostrea virginica (Gmelin) and the hard clam Mercenaria mercenaria (L.). Aquaculture, 18: 121.

Flassch, J.P., Woitellier, E. 1977. L'Elevage de L'Ormeau (Haliotis tuberculata L.) 1. Action d'un Regime Alimentaire D'Algues Phytoplanctoniques sur la Croissance post-larvair. Third Meeting of the I.C.E.S. Working Group on Mariculture, Brest France, May 10-13, 1977. Actes de Colloques du C.N.E.X.O.,4: 287-305. 
Fogg, G.E. 1965. Algal Cultures and Phytoplankton Ecology. The University of Wisconsin Press, Milwaukee. $126 \mathrm{pp}$.

Garland, C.D., Cooke,S., Grant, J.F., McMeekin,T.A. 1985. Ingestion of the Bacteria on and the Cuticle of Crustose (non-articulated) Coralline Algae by Post-Larval and Juvenile Abalone (Haliotis ruber Leach) from Tasmanian Waters. J. Exp. Mar. Biol. Ecol., 91: 137-149.

Genade, A.B., Hirst, A.L., Smit, C.J. 1988. Observations on the Spawning, Development and Rearing of the South African abalone Haliotis midae L. S. Afr. J. Mar. Sci., 6: 3-12.

Hadfield, M.G. 1984. Settlement requirements of molluscan larvae: New data on chemical and genetic roles. Aquaculture, 39: 283-298.

Hahn, K.O. 1989. Nutrition and Growth of Abalone. in Handbook of Culture of Abalone and Other Marine Gastropods (edited by Hahn, K.O.), 135-154. CRC

Hayashi, !. 1982. Small Scale Laboratory Culture of the Ormer, Haliotis tuberculata. J. Mar. Biol. Assn. U.K., 62: 835-844.

Helm, iM.M., Holland, D.L., Stephenson, R.R. 1973. The Effect of Supplementary Algal Feeding on a Hatchery Breeding Stock of Ostrea edulis L. on Larval Vigor. J. Mar. Biol. Assn. U.K. 53: 673-684.

Holland, D.L., Spencer, B.E. 1971. Biochemical Changes in Fed and Starved Oysters Ostrea edulis, during larval delelopment, metamorphosis and early spat growth. J. Mar. Biol. Assn. U.K., 53: 287-298.

Hooker, N., Morse, D.E. 1985. Abalone: The Emerging Development of Commercial Cultivation in the United States. in Crustacean and Mollusk Aquaculture in the United States (edited by Huner, J.V. and Brown, E.E.),365Humphrey, G.F. 1979. Photosynthetic Charactristics of Algae Grown Under Constant Illumination and Light-Dark Regimes. J. Exp. Mar. Biol. Ecol.,40: 6370.

Inoue, M., 1976. Awabi. In: Suisan Zoyoshoku Deeta Bukku. (Abalone. In: Fisheries Propagation Data Book). Published by Suisan Suppan (translated by M. Mottett, 1978).

Jaeckle, W.B., Manahan, D.T. 1989a. Feeding by an "nonfeeding" larva: uptake of dissolved amino acids from seawater by lecithotropic larvae of the gastropod Haliotis rufescens. Mar. Biol., 103: 87-94.

Jaeckle, W.B., Manahan, D.T. 1989b. Growth and Energy Imbalance During the Development of a Lecithotrophic Molluscan Larva (Haliotis rufescens). Biol. Bull., 177: 237-246. 
Jahnke, J. 1989. The Light and Temperature Dependence of Growth Rate and Elemental Composition of Phaeocystis globosa Scherfeel and $P$. pouchetii (Har.) Lagerh. in Batch Cultures. Neth. J. of Sea Res., 23(1): 15-21.

Jerlov, N.G. 1976. Marine Optics. Elsevier Oceanography Series, No. 14, 128-129.

Kan-no, H. 1975. Recent Advances in Abalone Culture in Japan. in Proceedings of the First International Conference on Aquaculture Nutrition. October,1975: 195-211.

Keller, M.D., Bellows, W.K., Guillard, R.R.L. 1988. Microwave Treatment for Sterilization of Phytoplankton Culture Media. J. Exp. Mar. Biol. Ecol.,117: 279283.

Koike, Y. 1978. Biological and Ecological Studies on the Propogation of the Ormer, Haliotis tuberculata Linneaus. I. Larval Development and Growth of Juveniles. La mer (Bulletin de la Societe franco-japanais d'oceanographie), Lees, A.D. 1968. Photoperiodism in Insects. in Photophysiolegy: Current Topics (edited by Geise,A.C.), 47-123. Academic Press, New York.

Leighton, D.L. 1972. Laboratory Observations on the Early Growth of the abalone, Haliotis sorenseni, and the Effect of Temperature on Larval Development and Settling Sucress. Fish. Bull., 70: 373-381.

Leighton, D.L. 1974. The Influence of Temperature on Larval and Juvenile Growth in Three Species of Southern California Abalones. Fish. Bull., 72(4): 1137-1145.

Leighton, D.L. 1977. Some Problems and Advances in Culture of North American Abalones (Haliotis), 1-14. Proc. Symp. Latin Am. Aquacult. Assoc. Maracay, Venezuela.

Leighton, D.L. 1985. Early Growth of Green Abalone in Hatchery and Field. Proc. Joint International Scientific Diving Sym., La Jolla, California. Nov. 1 - 3, 1985.

Manahan D.T., Stephens, G.C. 1983. The Use of High Performance Liquid Chromatography to Measure Dissolved Organic Compounds in Bivalve Aquaculture Systems. Aquaculture 32: 339-346.

Manzi, J.J., Burrell, V.G. Jr., Clawson, H.Q. M. 1981. Commercialization of Hard Clam (Mercenaria mercenaria) Mariculture in South Carolina: Preliminary Report. J. World Maric. Soc., 12(1): 181-195. 
Morse, D.E. 1981. Biochemical and genetic control of critical physiological processes in molluscan lifecycles: Basic mechanisms, water quality requirements and sensitivites to pollutants. Sea Grant College Program 19781980 Biennial Report, 83-87. University of California, La Jolla, California.

Morse, D.E. 1984.. Biochemical and Genetic Engineering for Improved Production of Abalones and other Valuable Molluscs. Aquaculture, 39: 263282.

Norman-Boudreau, K., Burns, D., Cooke, C.A., Austin, A. 1986. A simple Technique for Detection of Feeding in Newly Metamorphosed Abalone. Aquaculture, 51: 313-317.

Oba, T. 1964. Studies on the Propagation of an abalone, Haliotis diversicolor supretexta Lischke II. On the Development. Bull. of Jap. Soc. of Sci. Fish., 30: 809-818.

Parsons,T.R., Stephens, K., Strickland, J.D.H. 1961. On the Chemical Composition of Eleven Species of Marine Phytoplankters. J. Fish. Res. Bd. Canada, 18(6): 1101-1015.

Parsons, T.R., Maita, Y., Lalli, C.M. 1984. A Manual of Chemical and Biological Methods for Sea Water Analysis. Pergammon Press, New York. 173 pp.

Scheffe, H. 1959. The Analysis of Variance. John Wiley and Sons, Inc., New York, 477 pp.

Searcy-Bernal, R., Salas-Garza, A.E., Flores-Aguilar, R. 1989. Postlarval and Juvenile Growth of green abalorie (Haliotis fulgens) in a Mexican Laboratory. Ciencias Marinas. 14(4): 57-72.

Seki, T. 1980. An Advanced Biological Engineering System for Abalone Seed Production. in Proc. Inter. Symp. On Coastal Pacific Marine Life, Oct. 15-16, 1979, 45-54.

Shibui,T., 1972. On the Normal Development of the eggs of Japanese abalone, Haliotis discus hannai Ino, and ecological and physiological studies of its larvae and young. Bull. Iwate Pref. Fish. Exp. Stn. 2: 1-69.

Sokal, R.R., Rohlf, F.J. 1981. Biometry. The Principles and Practice of Statistics in Biological Research, 2nd ed. W.H. Freeman and Co., San Francisco. 859 pp.

Stein, J.R. 1973. Handbook of Phycological Methods: Culture Methods and Growth Measurements. Cambridge at the University Press. 448 pp.

Uki, N. 1981. Feeding Behavior of Experimental Populations of the abalone, Haliotis discus hannai. Bull. Tohoku Reg. Fish. Res. Lab., 43: 53-58. 
Underwood, A.J. 1981. Techniques of Analysis of Variance in Experimental Marine Biology and Ecology. Oceanogr. Mar. Biol. Ann. Rev.19: 513-605.

Weldon, C.W., Slauson, W.L. 1986. The Intensity of Competition Versus Its Importance: An Overlooked Distinction and Some Implications. Qrtly. Rev. Biol., $61(1): 23-44$.

Winer, B.J. 1971. Statistical Principles in Experimental Design, 2nd ed. McGraw-Hill Book Co., New York. 907 pp.

Whyte, J.N.C., Bourne, N., Hodgson, C.A. 1987. Assessment of Biochemical Composition and Energy Reserve in Larvae of the Scallop Patinopecten yessoensis. J. Exp. Mar. Biol. Ecol.,113: 113-124.

Whyte, J.N.C., Bourne, N., Hodgson, C.A. 1989. Influence of Algal Diets on Biochemical Composition and Energy Reserves in Patinopecten yessoensis (Jay) Larvae. Aquaculture, 78: 333-347.

Zar, J.H. 1984. Biostatistical Analyssis, 2nd ed. Prentice-Hall Inc., New Jersey, $715 \mathrm{pp}$. 
Table 1. Diatom inocula (cells $/ \mathrm{cm}^{2} \times 10^{3}$ ) for test containers. Time 0 is one day before the beginning of the experiment. Time 1 is the first sampling time or two weeks after the start of the experiment.

\begin{tabular}{llll} 
Time & N. closterium & N.zostereti & N. bilobata \\
\hline 0 & 72 & 79 & 67 \\
1 & 28 & 28 & 33 \\
2 & 41 & 135 & 107 \\
3 & 68 & 73 & 66 \\
4 & 106 & 65 & 73
\end{tabular}


Table 2. Haliotis rufescens. Mean shell length at the beginning of the experiment $(x \pm S E, n=5)$.

$\begin{array}{llll}\text { Mean Abalone } & \text { Sample 1 } & \text { Sample 2 } & \text { Sample 3 } \\ \begin{array}{l}\text { Shell Length } \\ (\mathrm{mm} \pm \text { SE) }\end{array} & .265 \pm .002 & .261 \pm .002 & .261 \pm .002\end{array}$


Table 3. Haliotis rufescens. ANOVA for Shell Length ( ${ }^{*}$ denotes significance at $\mathrm{p}<.05)$.

\begin{tabular}{|c|c|c|c|c|}
\hline $\begin{array}{l}\text { Source } \\
\text { Diet (D) } \\
\text { Light (L) } \\
D \times L \\
\text { Time (T) } \\
D \times T \\
L \times T \\
D \times L \times T \\
C \text { (DLT) } \\
\text { error }\end{array}$ & $\begin{array}{l}\frac{d f}{2} \\
1 \\
2 \\
4 \\
8 \\
4 \\
8 \\
60 \\
360\end{array}$ & $\begin{array}{l}\text { Mean Square } \\
.986 \\
3.656 \\
.376 \\
9.761 \\
.166 \\
.691 \\
.201 \\
.032 \\
.019\end{array}$ & $\begin{array}{l}\text { E ratio } \\
30.81^{\star} \\
114.25^{\star} \\
11.75^{\star} \\
305.03^{\star} \\
5.18^{\star} \\
21.59^{\star} \\
6.28^{\star} \\
1.68^{\star}\end{array}$ & $\begin{array}{l}\text { Importance } \\
.033 \\
.061 \\
.012 \\
.652 \\
.022 \\
.046 \\
.026 \\
.032 \\
.113\end{array}$ \\
\hline
\end{tabular}


Table 4. Haliotis rufescens. Growth rate in $\mu \mathrm{m} /$ day for each diet, irradiance and time. Values are differences between sample $(n=3)$ means.

\begin{tabular}{|c|c|c|c|c|c|c|}
\hline Age (weeks) & N. Cl & sterium & $\mathrm{N}, \mathrm{zO}$ & tereti & N. bil & bata \\
\hline & High & Low & High & Low & High & Low \\
\hline $1-3$ & 11 & 13 & $\overline{13}$ & 13 & $\overline{14}$ & 14 \\
\hline $3-4$ & 8 & 5 & 7 & 7 & 11 & 7 \\
\hline $5-$ & 22 & 6 & 22 & 4 & 20 & 13 \\
\hline $7-9$ & 11 & 18 & 21 & 19 & 28 & 17 \\
\hline $9-11$ & 7 & 17 & 23 & 4 & 35 & 12 \\
\hline
\end{tabular}


Table 5. Haliotis rufescens. ANOVA for Proportional Survival (" denotes significance at $(p<.05)$.

\begin{tabular}{|c|c|c|c|c|}
\hline $\begin{array}{l}\frac{\text { Source }}{\text { Diet (D) }} \\
\text { Light (L) } \\
D \times L \\
\text { Time (T) } \\
D \times T \\
L \times T \\
D \times L \times T \\
\text { error }\end{array}$ & $\begin{array}{l}\frac{d f}{2} \\
1 \\
2 \\
3 \\
6 \\
3 \\
6 \\
48\end{array}$ & $\begin{array}{l}\text { Mean Square } \\
2973.755 \\
366.592 \\
199.344 \\
512.042 \\
164.200 \\
849.880 \\
264.800 \\
93.015\end{array}$ & $\begin{array}{l}\text { E ratio } \\
31.971^{\star} \\
3.941 \\
2.143 \\
5.505^{\star} \\
1.765 \\
9.137^{\star} \\
2.847^{\star}\end{array}$ & $\begin{array}{l}\text { Importance } \\
.33 \\
.02 \\
.02 \\
.08 \\
.05 \\
.14 \\
.08 \\
.25\end{array}$ \\
\hline
\end{tabular}


Table 6. Mean diatom cell density (cells/cm $2 \times 10^{3} \pm \mathrm{SE}$ ). Controls represent diatom growth for each two week sampling period in test containers without abalone. 'Abs' represent diatom growth from inoculum added successivley each two weeks. Times $1,2,3,4$, and 5 are shown in the treatment column.

\begin{tabular}{|c|c|c|c|}
\hline $\begin{array}{l}\text { Treatment } \\
\text { control-high-1 } \\
\text { control-low-1 } \\
\text { abs-high-1 } \\
\text { abs-low-1 } \\
\text { control-high-2 } \\
\text { control-low-2 } \\
\text { abs-high-2 } \\
\text { abs-low-2 } \\
\text { control-high-3 } \\
\text { control-low-3 } \\
\text { abs-high-3 } \\
\text { abs-low-3 } \\
\text { control-high-4 } \\
\text { control-low-4 } \\
\text { abs-high-4 } \\
\text { abs-low-4 } \\
\text { control-high-5 } \\
\text { control-low-5 } \\
\text { abs-high-5 } \\
\text { abs-low-5 }\end{array}$ & $\begin{array}{l}\text { N. bilobata } \\
448 \pm 125 \\
269 \pm 66 \\
128 \pm 21 \\
\frac{34 \pm 12}{999 \pm 145} \\
366 \pm 213 \\
390 \pm 142 \\
268 \pm 14 \\
433 \pm 201 \\
258 \pm 46 \\
1045 \pm 389 \\
\frac{393 \pm 97}{867 \pm 72} \\
431 \pm 104 \\
2356 \pm 998 \\
\frac{465 \pm 70}{347 \pm 7} \\
214 \pm 3 \\
3159 \pm 289 \\
1147 \pm 239\end{array}$ & $\begin{array}{l}\text { N. closterium } \\
459 \pm 28 \\
204 \pm 51 \\
540 \pm 105 \\
258 \pm 52 \\
154 \pm 18 \\
19 \pm 4 \\
267 \pm 74 \\
203 \pm 128 \\
1017 \pm 41 \\
2159 \pm 857 \\
666 \pm 477 \\
441 \pm 223 \\
1230 \pm 50 \\
2413 \pm 343 \\
5853 \pm 675 \\
1963 \pm 206 \\
901 \pm 6 \\
706 \pm 10 \\
12600 \pm 260 \\
5570 \pm 230\end{array}$ & $\begin{array}{l}\frac{N}{\text { z zostereti }} \\
164 \pm 23 \\
45 \pm 20 \\
434 \pm 162 \\
\frac{95 \pm 19}{105 \pm 3} \\
79 \pm 21 \\
288 \pm 88 \\
109 \pm 2 \\
\text { no data } \\
\text { no data } \\
1353 \pm 190 \\
1006 \pm 24 \\
620 \pm 103 \\
95 \pm 13 \\
3620 \pm 450 \\
2433 \pm 733 \\
478 \pm 3 \\
289 \pm 5 \\
3370 \pm 614 \\
1210 \pm 251\end{array}$ \\
\hline
\end{tabular}


Table 7. Mean Chl a content ( $\mu \mathrm{g} / \mathrm{ml} \pm \mathrm{SE}$ ). Controls represent diatom growth for each two week sampling period. 'Abs' treatment are diatom growth with successive additions of inoculum. Times 1,4 , and 5 are shown in the treatment column.

\begin{tabular}{|c|c|c|c|}
\hline $\begin{array}{l}\text { Ireatment } \\
\text { control-high-1 } \\
\text { control-low-1 } \\
\text { abs -high-1 } \\
\text { abs -low-1 }\end{array}$ & $\begin{array}{l}\text { N. bilobata } \\
275 \pm .275 \\
195 \pm 7.57 \\
112 \pm .375 \\
23 \pm 2.01\end{array}$ & $\begin{array}{l}\text { N. closterium } \\
389 \pm 1.051 \\
23 \pm 2.278 \\
37 \pm 1.873 \\
264 \pm 2.59\end{array}$ & $\begin{array}{l}\text { N. zostereti } \\
155 \pm 2.99 \\
26 \pm 1.09 \\
60 \pm .668 \\
74 \pm 2.23\end{array}$ \\
\hline $\begin{array}{l}\text { control-high-4 } \\
\text { control-low-4 } \\
\text { abs -high- } 4 \\
\text { abs-low- } 4\end{array}$ & $\begin{array}{l}291 \pm 9.03 \\
140 \pm 2.37 \\
590 \pm 2.27 \\
370 \pm 2.66\end{array}$ & $\begin{array}{l}101 \pm 1.725 \\
93 \pm 1.845 \\
302 \pm 2.35 \\
178 \pm 2.83\end{array}$ & $\begin{array}{l}238 \pm 10.23 \\
231 \pm 1.059 \\
496 \pm 3.04 \\
121 \pm 2.82 \\
\end{array}$ \\
\hline $\begin{array}{l}\text { control-high-5 } \\
\text { control-low-5 } \\
\text { abs -high }-5 \\
\text { abs -low }-5\end{array}$ & $\begin{array}{l}306 \pm 4.33 \\
230 \pm 2.97 \\
257 \pm 1.53 \\
579 \pm 7.51\end{array}$ & $\begin{array}{l}407 \pm .39 \\
301 \pm 2.28 \\
577 \pm 557 \\
7 \pm 1.864\end{array}$ & $\begin{array}{l}312 \pm 3.16 \\
195 \pm .667 \\
340 \pm 17.11 \\
380 \pm 1.93\end{array}$ \\
\hline
\end{tabular}


Table 8. CHN Analysis. Each value represents a mean of three subsamples taken from one sample of each diatom species \pm one standard error.

$\begin{array}{lllll}\text { Organism } & \% \mathrm{C} & \frac{\% \mathrm{H}}{\mathrm{C}} & \frac{\mathrm{N}}{\mathrm{N}} & \mathrm{C} / \mathrm{N} \\ \text {. closterium } & 9.107 \pm .454 & 3.260 \pm .670 & 1.584 \pm .029 & 5.749 \\ \text { N. zostereti } & 6.593 \pm .287 & 1.433 \pm .031 & 1.223 \pm .041 & 5.391 \\ \text { N. bilobata } & 7.984 \pm .120 & 1.618 \pm .077 & 1.465 \pm .200 & 5.449\end{array}$




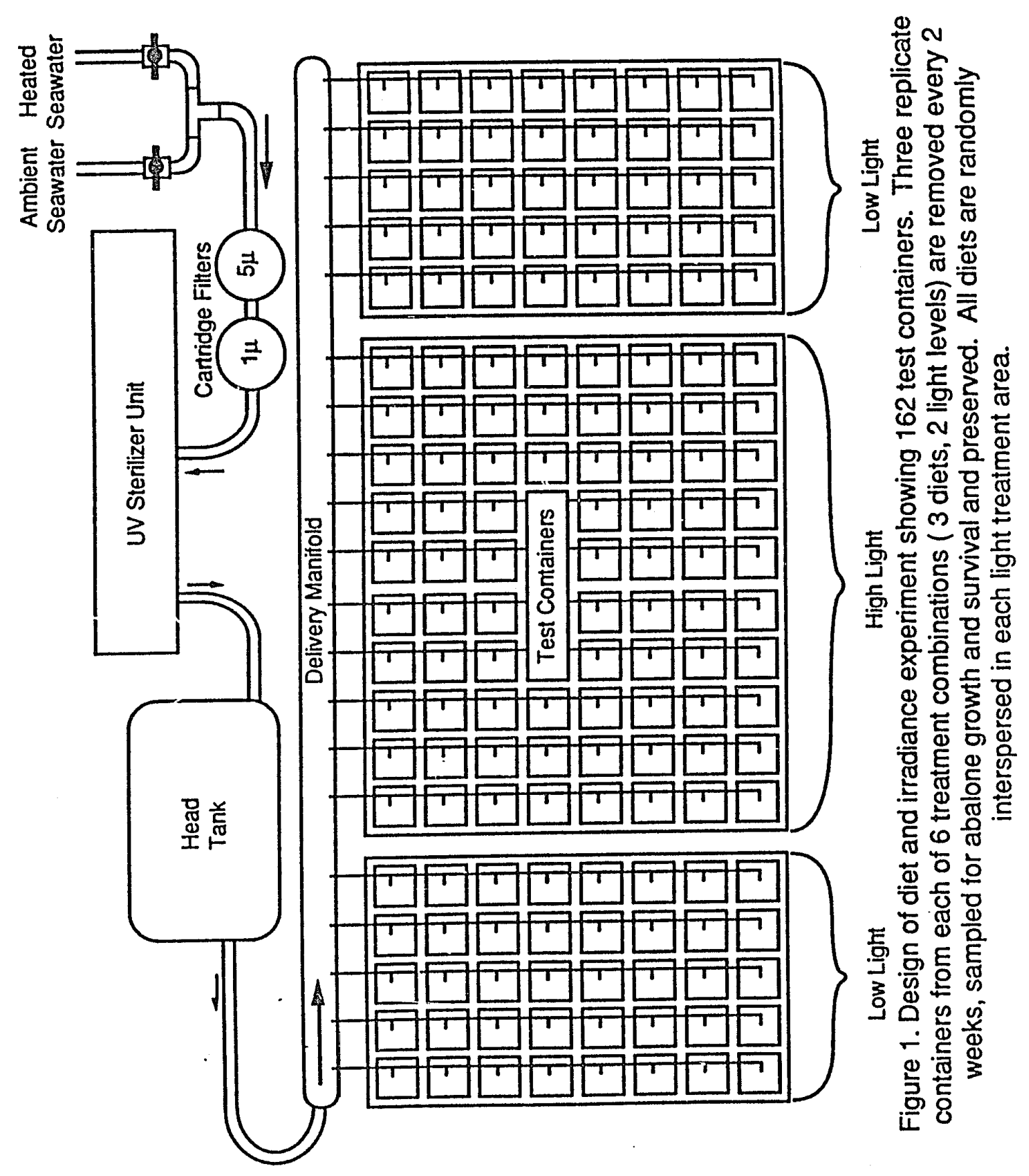



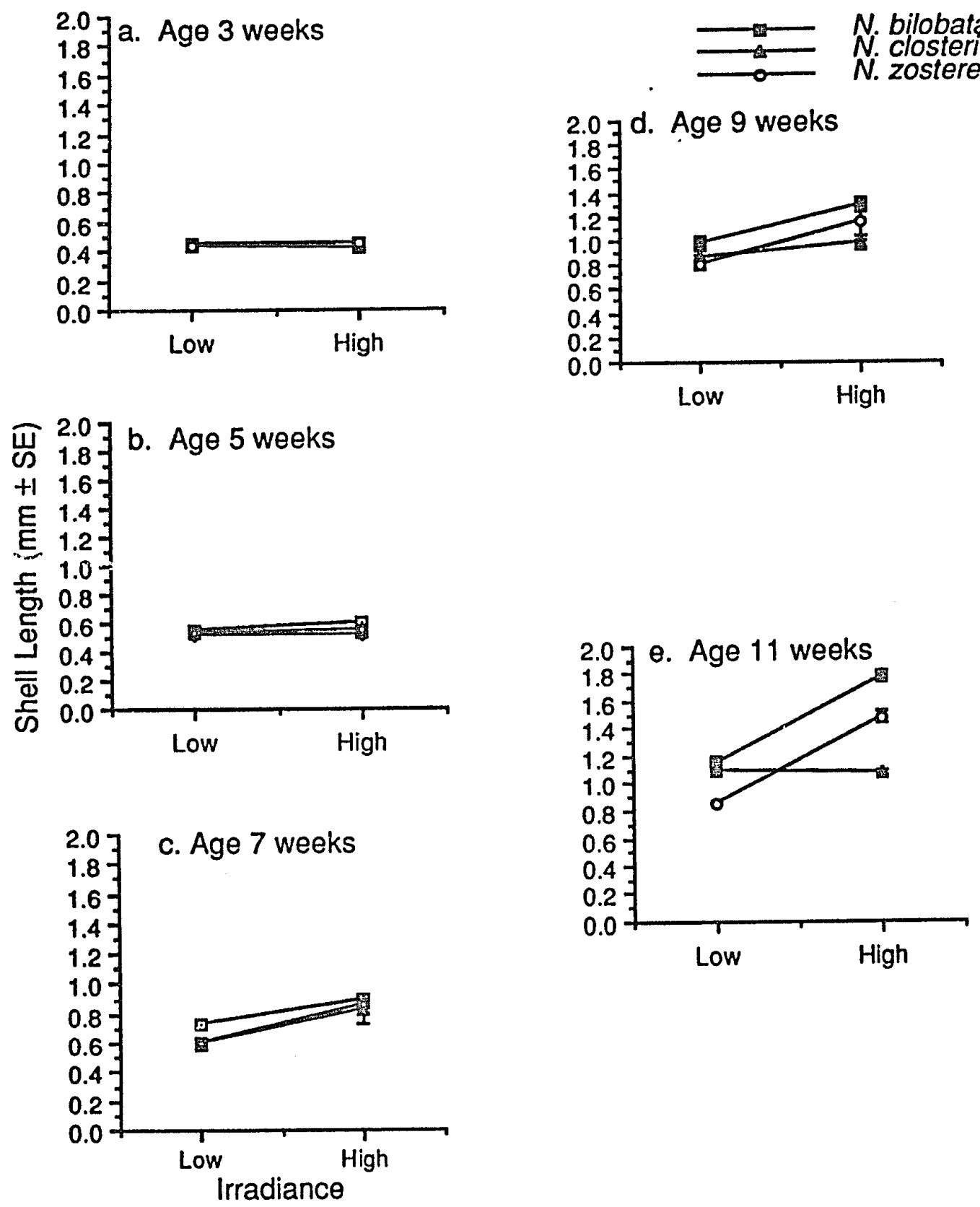

Figure 2. Effect of irradiance and time on mean abalone shell length for all diets at each two week sampling interval $(x \pm S E, n=3)$. 

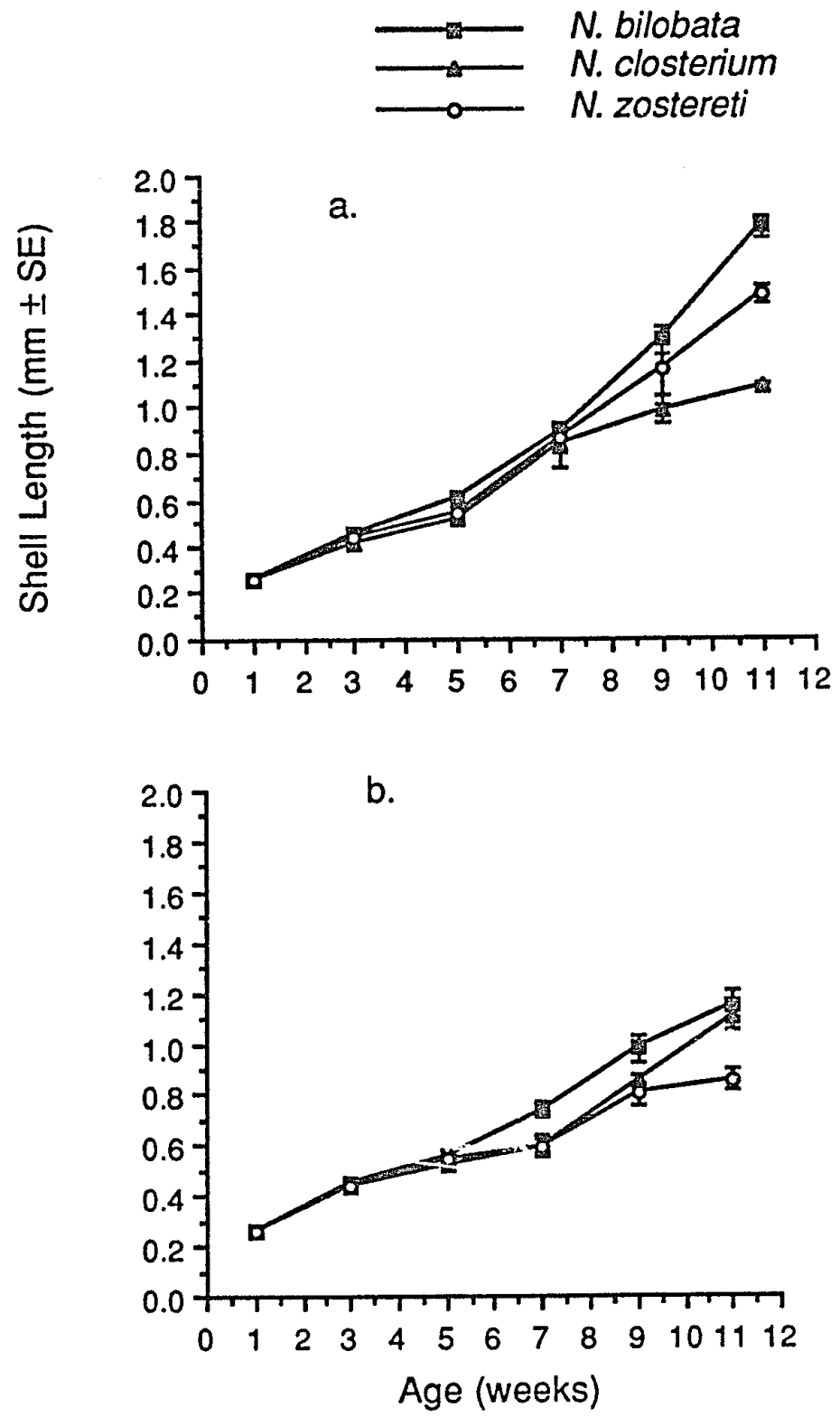

Figure 3. Effect of diet and time on abalone shell length for both light levels, $a$. high irradiance $(50-60 \mu \mathrm{E}) ; \mathrm{b}$. low irradiance $(15-25 \mu \mathrm{E})$. Data points indicate mean shell length, $x \pm S E, n=3$. 
a.

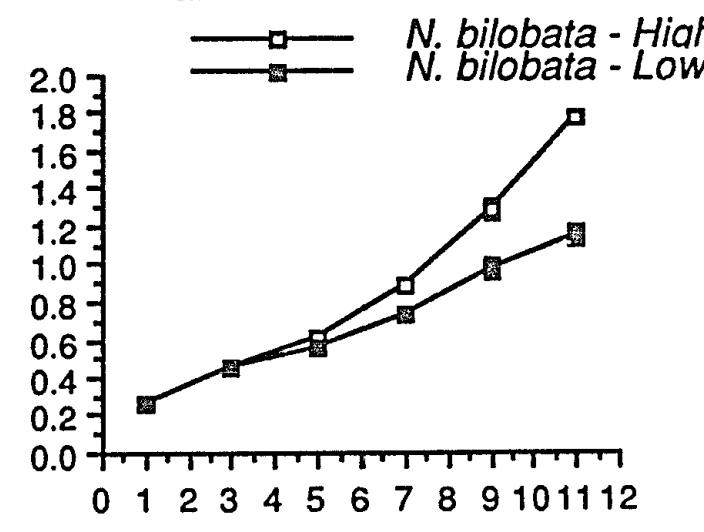

b.

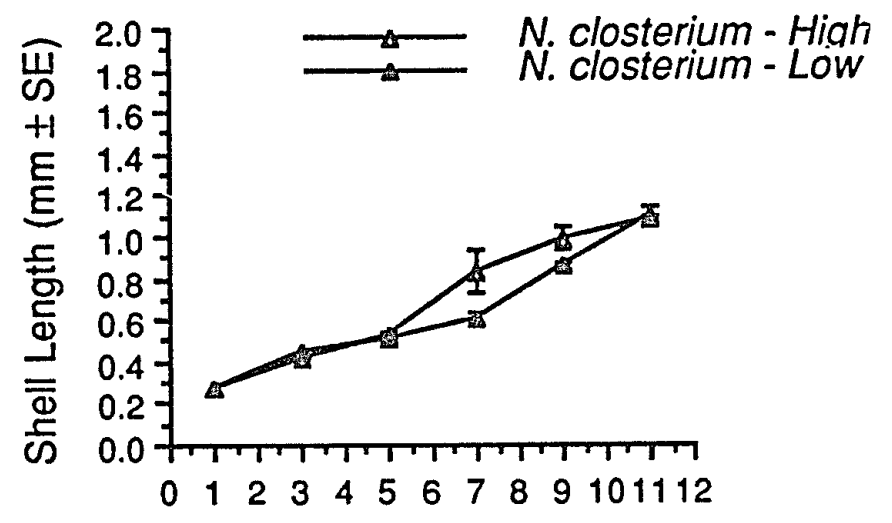

c.

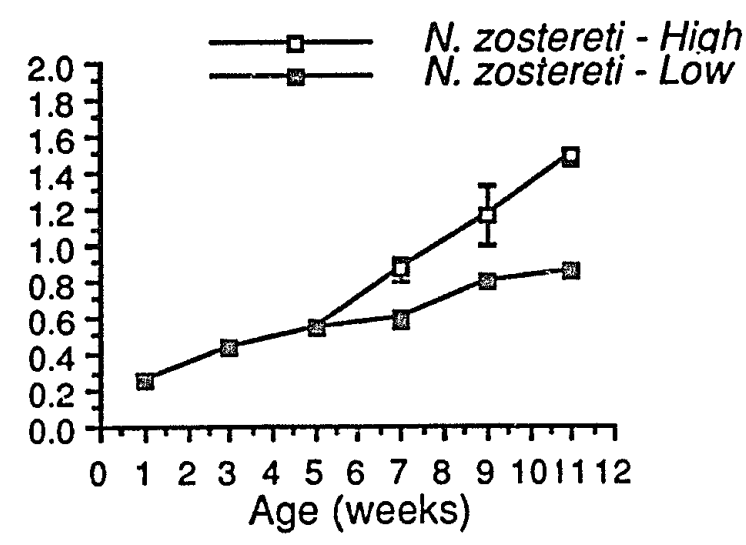

Figure 4. Effect of individual diet and irradiance level on mean abalone shell length for the ten week experiment, $x \pm S E, n=3$. 

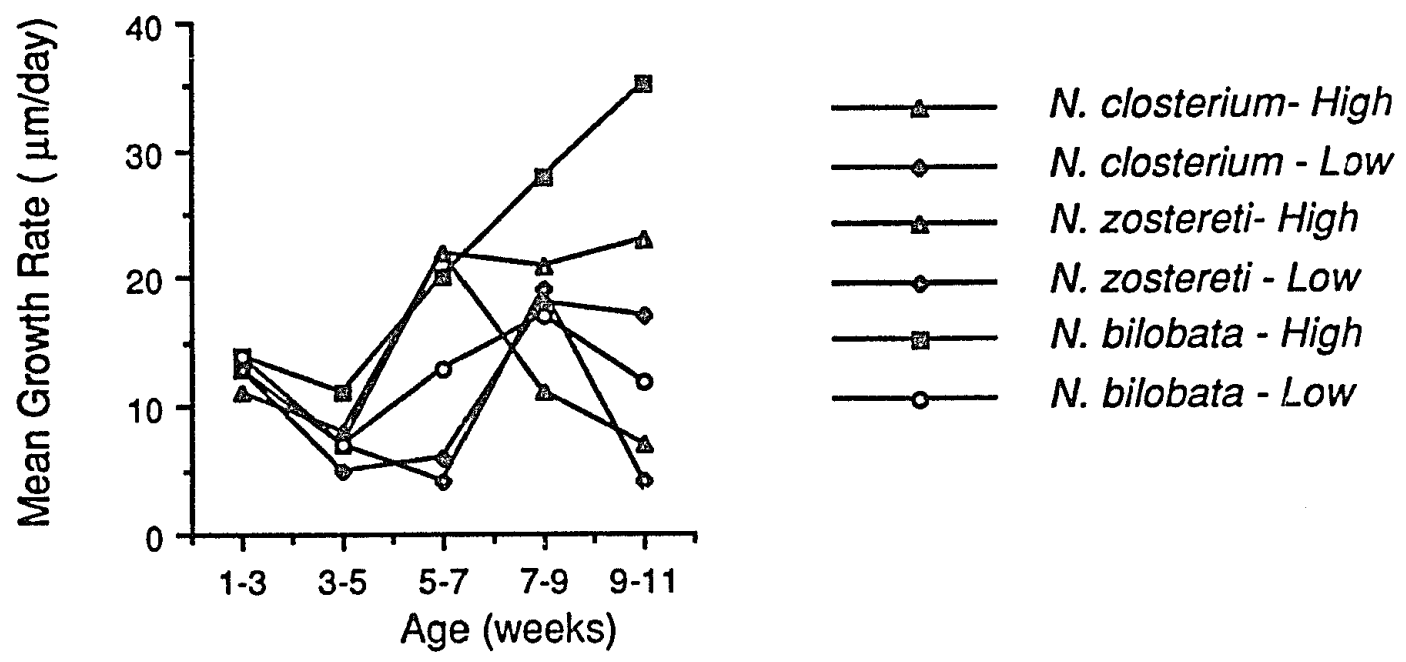

Figure 5. Mean abalone growth rates for all diet and light treatments calculated from sample means $(n=3)$. 


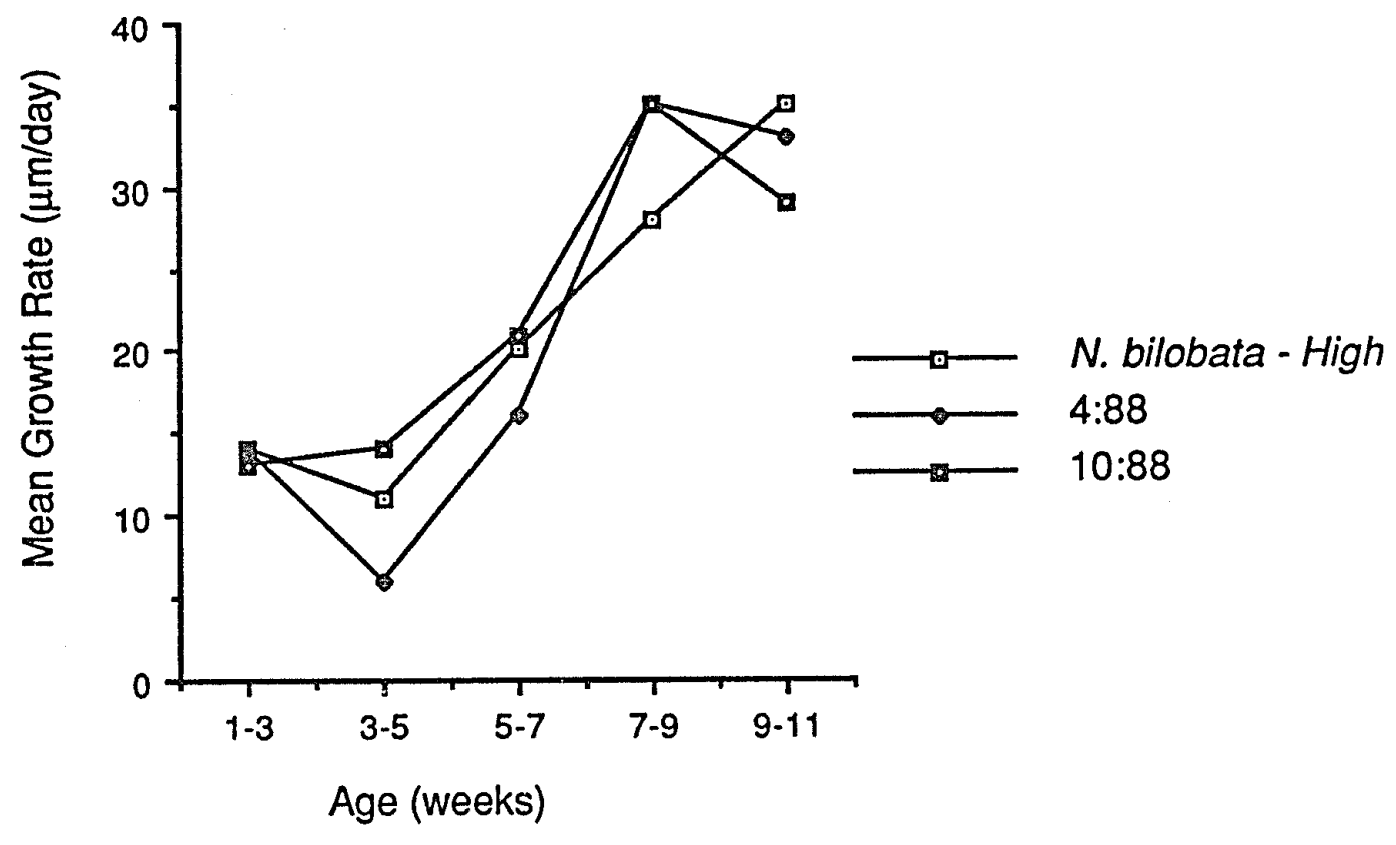

Figure 6. Mean growth rates of abalone from $N$. bilobata, high light treatment and from two miscellaneous spawnings of 1988 (4:88 and 10:88). 


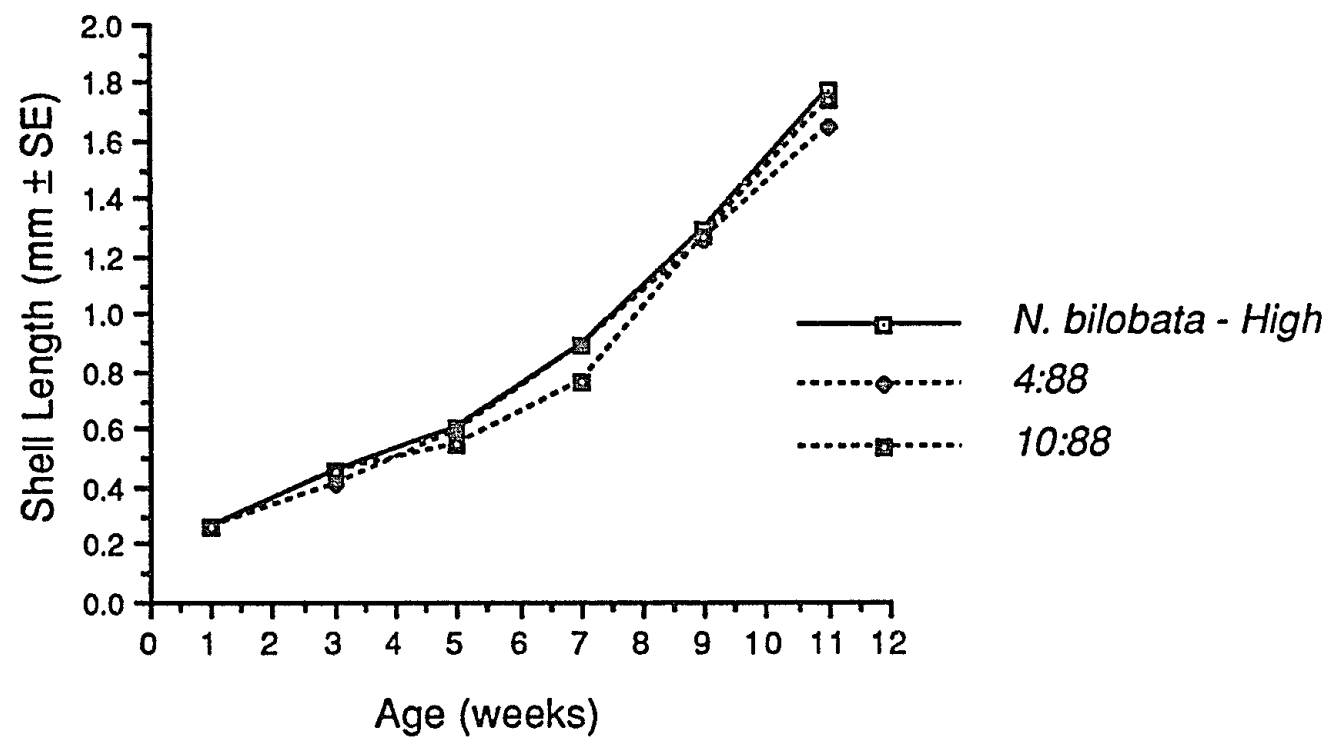

Figure 7. Mean shell length of abalone from N. bilobata, high irradiance treatment and two miscellaneous spawnings of 1988 (4:88 and 10:88) 

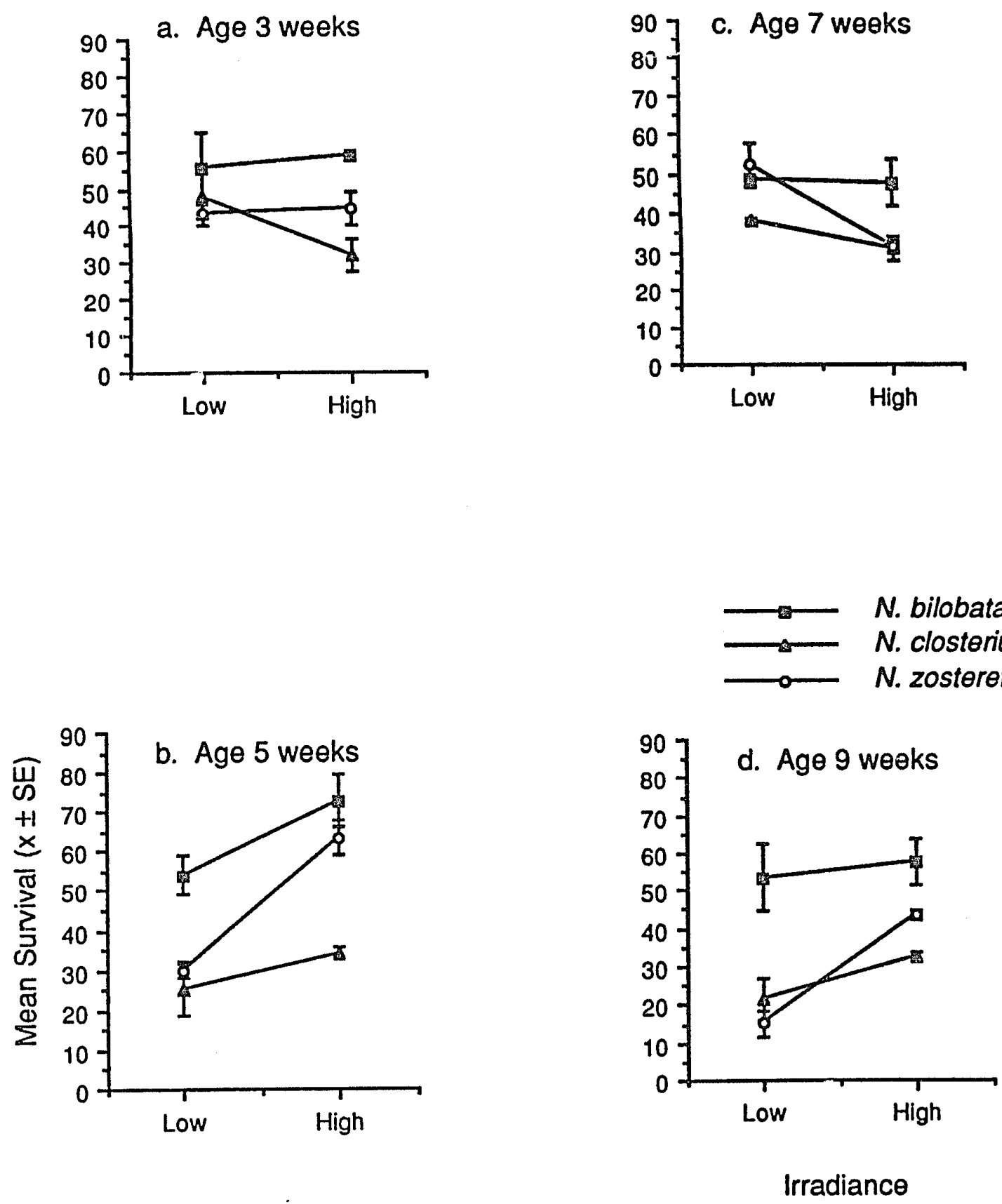

Figure 8. Effect of irradiance and time on mean proportional abalone survival for each diatom diet and at each two week sampling interval, $x \pm S E, n=3$. Data presented are $\arcsin \sqrt{x}$ where $90^{\circ}=100 \%$. 
a.
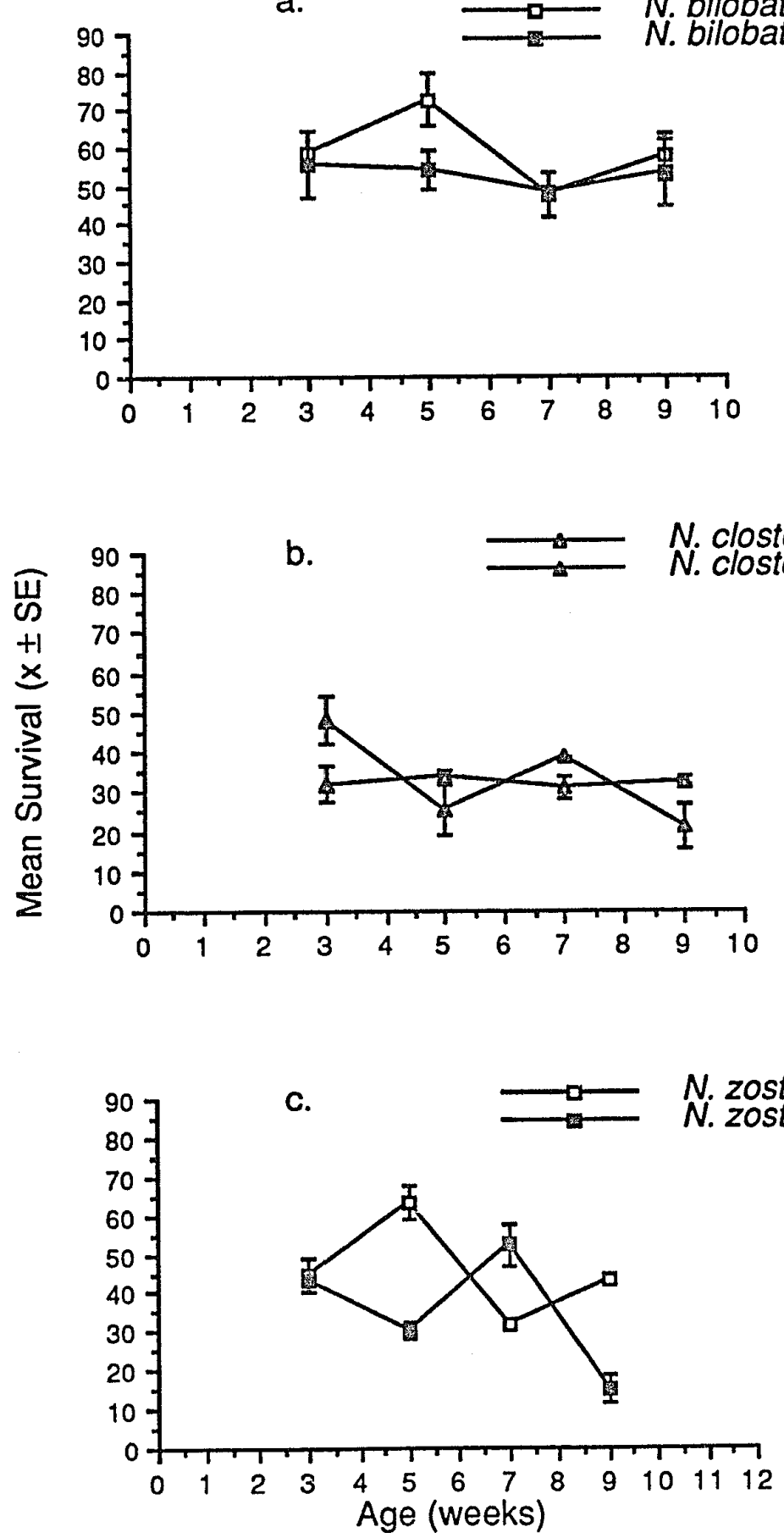

Figure 9. Effect of individual diet and irradiance levels on mean proportional abalone survival for the ten week experiment, $x \pm S E, n=3$. Data presented are transformed by arcsin $\sqrt{x}$. 

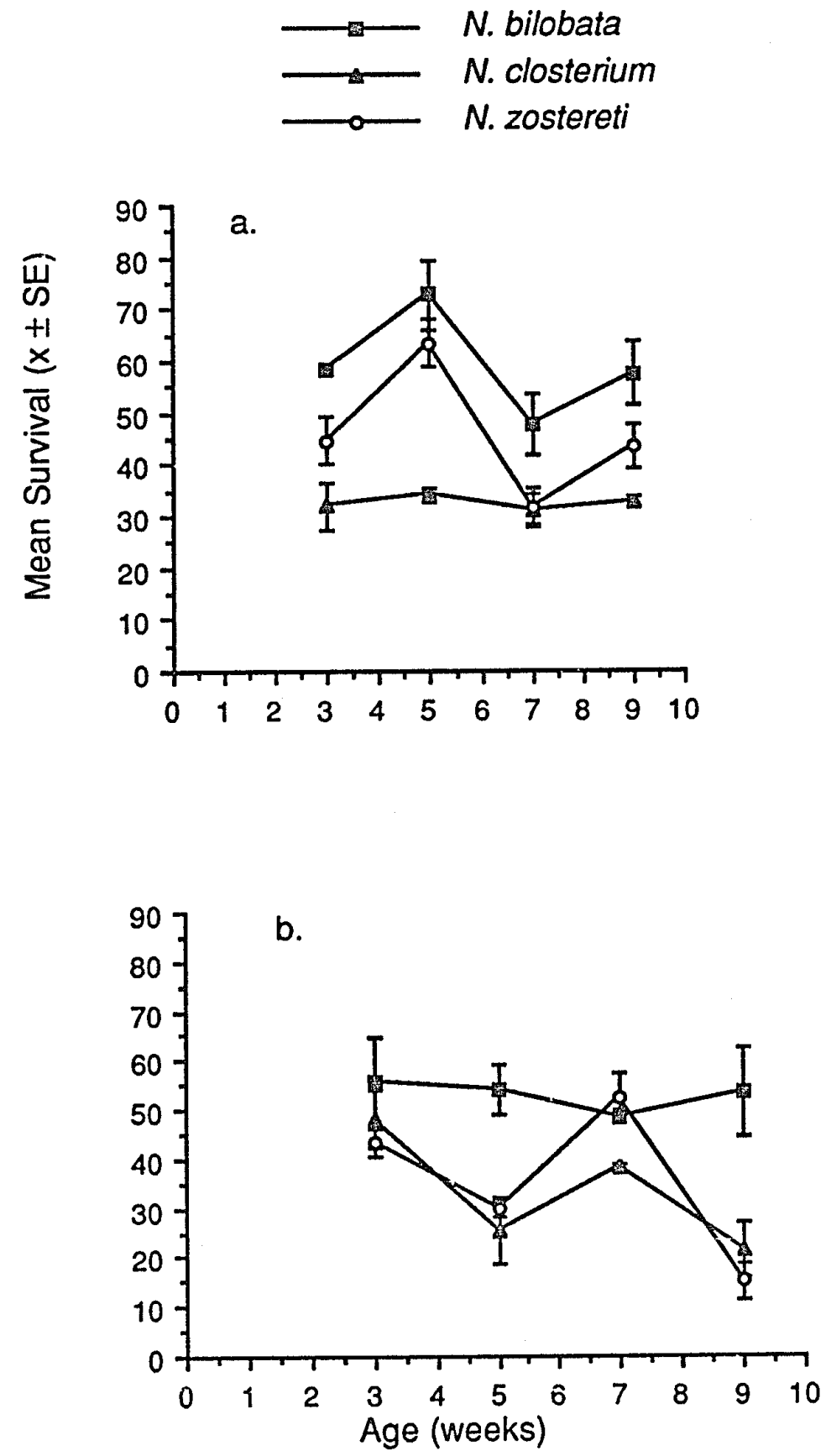

Figure 10. Effect of individual diet and time on mean proportional survival for both light levels, a. high irradiance, $50-60 \mu \mathrm{E}$; b. low irradiance, 15- $25 \mu \mathrm{E}$. Data presented are arcsin $\sqrt{ } x$ transformed, $x \pm S E, n=3$. 


\section{Appendix}

Mean Square Estimates for Analysis of Variance on Abalone Shell Length

Diet: $\vartheta_{e}+n \vartheta C(D L T)+I t c n \vartheta D$

Light: $\vartheta_{e}+n \vartheta C(D L T)+d t c n \vartheta L$

Diet $x$ Light: $\vartheta_{e}+n \vartheta C(D L T)+\operatorname{ten} \vartheta L D$

Time: $\vartheta_{e}+n \vartheta c(D L T)+I d c n \vartheta T$

Light $\times$ Time: $\vartheta_{e}+\vartheta C(D L T)+d c n \vartheta L T$

Diet x Time: $\vartheta_{e}+\vartheta C(D L T)+l c n \vartheta D T$

Diet $\times$ Light $\times$ Time: $\vartheta_{e}+\vartheta C(D L T)+$ cnvDLT

Containers: $\vartheta_{e}+\vartheta \mathrm{C}(\mathrm{DLT})$

Error: $\vartheta$

For these mean square estimates, $d, \mathrm{l}, \mathrm{t}$, and $\mathrm{c}$ are levels of the factors, diet (D), light $(L)$, time $(T)$, and container $(C)$, respectively. The symbol $\vartheta$ represents variance, the letter e signifies error, and the letter $n$ represents each individual shell length measurement. 